\title{
NUMERICAL DETERMINATION OF THE GAS-SIDE AVERAGE HEAT TRANSFER COEFFICIENTS IN THE FIN-AND-TUBE HEAT EXCHANGER
}

\begin{abstract}
This paper presents the numerical method for the determination of the average heat transfer coefficient in fin-and-tube heat exchanger. The air side Nusselt number formulas are determined via the CFD simulation based method. The path of the gas flow across the inter-tubular space of this heat exchanger is complex, therefore the CFD simulations are used to determine the velocity distributions and the temperature field of air. The results of the numerical computations are compared with the Nusselt number formula based on the experimental data, which were obtained during the test of the car radiator. Good agreement between the numerical results and the results based on the measurements is achieved.
\end{abstract}

Keywords: heat transfer coefficient, fin-and-tube heat exchanger, CFD simulations, oval tubes.

\section{Introduction}

Plate fin-and-tube heat exchangers are widely used in industrial plants and installations, as air-coolers, convectors for home heating and waste heat recovery for gas turbines, due to their large thermal efficiency. Such efficiency is achieved by the extended heat exchange surface consisting of the plate fins, which are assembled on the oval tubes of a heat exchanger. These heat exchangers operate in the cross-flow arrangements, with liquid (e.g. water or oil) flowing through the tubular space of the heat exchanger and gas (e.g. air, flue gas) flowing across the inter-tubular space of the heat exchanger. The large heat transfer area of the fins increases the heat transfer rate of gas flow. Moreover, the application of the oval tubes reduces pressure drop and improves heat trans-

\footnotetext{
${ }^{1}$ Dawid Taler, Cracow University of Technology, Warszawska 24, 31-155 Kraków, Poland, phone number: +48 12 6283026, e-mail: dtaler@pk.edu.pl

${ }^{2}$ Corresponding author Paweł Ocłoń: Cracow University of Technology, Al. Jana Pawła II 37,

31-864 Kraków, Poland, e-mail: poclon@mech.pk.edu.pl
} 
fer conditions by increasing the contact area between the gas and the tube surface, when compared with the circular tubes [1-4].

The performance of the fin-and-tube heat exchangers and their components has been widely studied in the literature [5-15]. The issues undertaken during the design procedure for these devices are: the efficiency analysis of heat transfer process, the determination of the average heat transfer coefficients for the fluids flowing in the tubular and the inter-tubular spaces of the heat exchangers, the analysis of flow distribution inside the tubular and inter-tubular space of the heat exchanger, the determination of the thermal contact resistance between the fin and the tube and the structural analysis of these devices.

In order to determine the overall heat transfer coefficient, it is necessary to determine the average values of the heat transfer coefficient for the fluids, between which the heat transfer occurs. It is difficult to predict properly these values, especially for the gas flow through the inter-tubular space of the heat exchanger, because the flow regime at the inlet to the heat exchanger is turbulent and changes to the laminar one at the inlet to the narrow passage, formed between the fins. Moreover, the large vortex zones occur below the oval profile, when the gas flows in the perpendicular direction to the tubes, what must be considered during the computations.

This paper presents both the experimental and numerical methods for the determination of the average heat transfer coefficients for air flow across the narrow passage formed between the plate fins of a fin-and-tube heat exchanger. The experimental tests are performed on the automotive car radiator, where the cold air flows through the inter-tubular space of the heat exchanger and is heated by water flowing inside the oval tubes welded to the sieve plate of the heat exchanger.

\section{Tested fin-and-tube heat exchanger}

The determination of the formulas for the heat transfer coefficient of gasside is performed for the narrow flow passage (see Fig. 1) formed between two consecutive fins, with fin spacing $s=1 \mathrm{~mm}$ and fin thickness $\delta_{f}=0.08 \mathrm{~mm}$. These fins are fixed to the oval tubes of the car radiator, presented in Fig 2. The tube and fin are made of aluminum $\left(k_{f}=k_{t}=207 \mathrm{~W} /(\mathrm{m} \mathrm{K})\right)$. The pitches of the tube arrangement in the perpendicular and longitudal directions are $p_{1}=18.5 \mathrm{~mm}$ and $p_{2}=17 \mathrm{~mm}$, respectively. The minor and major axes of the oval section are $d_{\min }=6.35 \mathrm{~mm}$ and $d_{\max }=11.82 \mathrm{~mm}$, and the tube wall thickness is equal $\delta_{t}=$ $0.4 \mathrm{~mm}$. The heat transfer coefficient for water flow is denoted as $h_{i n}$ and the bulk temperature of water flowing inside the tube is $T_{w}$.

Water, which is cooled down by the air flowing in the perpendicular direction to two rows of the oval tubes, flows inside the tubular space of the heat exchanger, which consists of: the inlet header, two rows of the tubes, the 
intermediate header and the outlet header, is subdivided into two passes. The inlet, the intermediate and the outlet temperatures of water are denoted as $T^{\prime}{ }_{w}$, $T{ }^{\prime}{ }_{w}$ and $T$ ', ${ }_{w}$, respectively. The air, with inlet velocity $w_{0}$, is heated when flowing through the inter-tubular space of the heat exchanger. The inlet, intermediate and outlet temperatures of the air are: $T{ }_{a}, T^{\prime \prime}{ }_{a}$ and $T{ }^{\prime \prime}{ }_{a}$, respectively. The car radiator consists of 38 tubes arranged in two passes. The upper pass contains two rows of 10 tubes each and the lower one contains two rows of 9 tubes each. The radiator is $520 \mathrm{~mm}$ wide, $359 \mathrm{~mm}$ high and $34 \mathrm{~mm}$ thick.
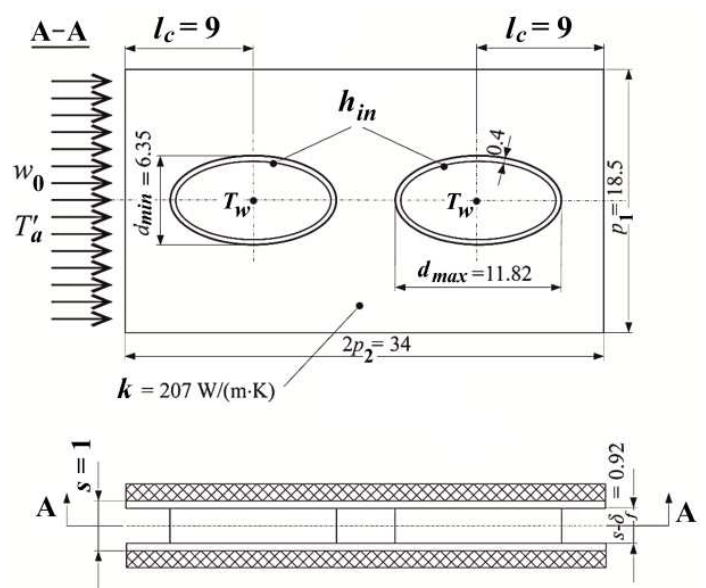

Fig. 1. Scheme of the narrow air flow passage across a car radiator.

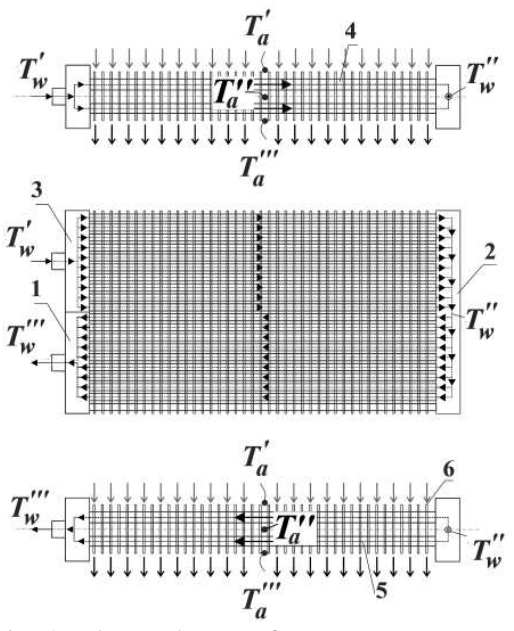

Fig. 2. Flow scheme of a two-pass tworow car radiator: 1 - outlet header, 2 intermediate header, 3 - inlet header, 4 oval tube (first row), 5 - oval tube (second row), 6 - plate fin.

\section{CFD simulation based method for determination of air-side heat transfer coefficient}

The heat transfer formulas for the air flow in the narrow passage, formed between two consecutive fins (see Fig.1) can be determined using the CFD simulations [16,17]. The CFD commercial code ANSYS CFX release 12 [16] enables the numerical solution of the differential mass, momentum and energy transport equations to obtain the fields of dependent variables in the fluid (air) and solid domains (tube, fin). In the fluid domain, the equations to be solved are the continuity, Navier-Stokes and energy transport equations. Although the Reynolds number (the definition of which is given in section 4) is low (approx. between $150-400$ ), the resulting flow structure with vortices in the wakes of 
the tubes imply that the flow may have a turbulent, or transitional character. For coping best with this circumstances, the SST turbulence model with the transitional Gamma-Theta turbulence formulation [18] is applied. Thus, Reynolds-averaged governing equations are solved, which are closed by the aforementioned turbulence model. In the solid domain, the single differential equation to be solved is the energy equation, describing the conduction heat transfer. For the solid regions, the material properties are assumed to be temperature independent. However, the temperature dependence of the air properties is taken into account. Tabulated temperature dependence of density $\rho$, viscosity $\mu$ and the isobaric heat capacity $c_{p}$ was incorporated via the CEL (CFX expression language). The differential governing equations are discretized by finite element based finite volume method. The momentum and continuity equations are solved in a coupled manner. A co-located grid definition is used, applying the Rhie-Chow interpolation scheme for pressure. The connective terms are discretized by the so-called "high resolution" scheme [16]. The numerical model and boundary conditions, applied to the computations, are presented in Fig. 3.

Three heat transfer domains are defined: the fluid domain, air -1 and solid domains: fin -2 and tube -3 . The inlet boundary condition, with the given values of air velocity $w_{0}=1 \mathrm{~m} / \mathrm{s}-2.5 \mathrm{~m} / \mathrm{s}$ and temperature $T^{\prime}{ }_{a}=14.98{ }^{\circ} \mathrm{C}$ is denoted as I. At the defined outlet of the domain (Figure 3, symbol II), a reverse flow may occur since the wake behind the tube can even reach the fin edge at the air outlet. For being able to cope with this situation and to prescribe the values of pressure and temperature of the recirculating flow, the so-called "opening" boundary of ANSYS CFX is applied. For this type of boundary condition the initial value of the area averaged static pressure and mass averaged static temperature in the next iteration

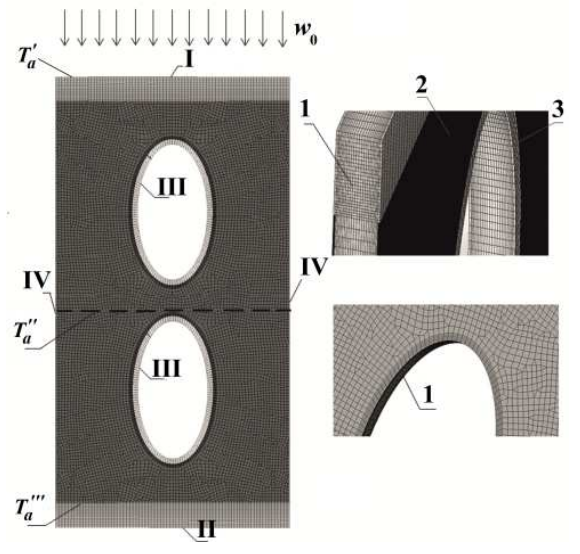

Fig. 3. The discrete model of flow across a single narrow passage between two fins: $1-$ fluid domain (air), 2 - solid domain (fin), 3 - solid domain (tube); boundary conditions: I - inlet, II - opening, III - convective surface, IV - symmetry. are equal to the corresponding values from the previous iteration. It leads to a converged and physically reasonable solution even in the case of recirculation at the outlet boundary. This approach ensures obtaining correct results. The convective surface boundary condition - III is applied to the inner surface of the tube wall to model the convective heat transfer from water. During the CFD computations, the heat transfer correlations for air side are determined, thus for 
water flow the values of the heat transfer coefficient $h_{i n}=4795 \mathrm{~W} /\left(\mathrm{m}^{2} \mathrm{~K}\right)$ and bulk temperature $\bar{T}_{w}=65^{\circ} \mathrm{C}$ and $\bar{T}_{w}=30^{\circ} \mathrm{C}$, are held constant. Only the inlet velocity of the air $w_{0}$ is varying during the consecutive computational cases. The symmetry boundary condition is applied at location IV.

The results of the CFD simulation are presented in Fig. 4. The discrete model used in the CFD simulation, is refined in the near wall regions in order to improve the prediction of the heat flux at the fluid-solid interface. The further refinement of the discrete model presented in Fig. 3 does not change the values of temperature and velocity, and heat flux by more than $0.01 \%$.

Fig. 4a presents velocity distribution of the air flowing through a narrow passage formed between two consecutive fins. The stagnation zones occur beneath the tube in the first row and beneath the tube in the second one. These zones expand with the increase of inlet velocity of the air $w_{0}$ (compare Fig. 4, $w_{0}=1 \mathrm{~m} / \mathrm{s}$ and $w_{0}=2.5 \mathrm{~m} / \mathrm{s}$ ), reducing significantly the heat transfer ability.

The distributions of: the air temperature (evaluated at the middle of the flow passage) and the fin and tube temperature are presented in Fig. 4b and Fig. 4c respectively. In Fig. 4c, one can observe that the rate of temperature changes along the flow direction is larger for the tube in the first row than the tube in the second one. This occurs due to the presence of the stagnation zones beneath and above the second row of tubes, that reduce the heat flux across the outer surface of the tube wall.

The average heat transfer coefficients were determined, based on the following relationship:

$$
h_{\text {avg }, \text { CFD }}=Q /\left(A_{t}\left(\bar{T}_{\text {wall }}-T_{\infty}\right)\right) \text {, }
$$

where the heat transfer rate, referenced to a single pitch, is defined as:

$$
Q=\dot{m}\left(i_{0, \text { outet }}-i_{0, \text { inlet }}\right),
$$

where $\dot{m}$ denotes the mass flow rate of the air, $i_{0, \text { outlet }}$ and $i_{0, \text { inlet }}$ are the static enthalpy of the air at the outlet and inlet of the narrow flow passage, respectively. The total heat transfer area is defined as:

$$
A_{t}=A_{f}+A_{e}
$$

where $A_{f}$ is the surface area of the fin and $A_{e}$ is the area of a tube external surface. The area averaged wall temperature is given by:

$$
\bar{T}_{\text {wall }}=\left(1 / A_{t}\right) \int_{A_{t}} T_{\text {wall }} d A,
$$


The bulk temperatureof air $T_{\infty}$ can be calculated based on the inlet and outlet air temperature, assumed as the arithmetic mean temperature:

$$
T_{\infty}=\bar{T}_{a}=0.5\left(T_{a}^{\prime}+T_{a}^{\prime \prime \prime}\right)
$$

a) $\quad w_{0}=1 \mathrm{~m} / \mathrm{s}, T_{0}=14.98^{\circ} \mathrm{C}$

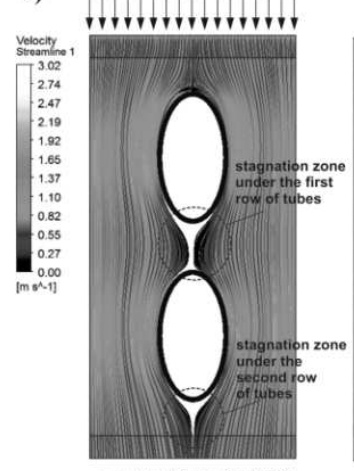

$w_{1}=1.6 \mathrm{~m} / \mathrm{s}, T_{0}=14.98^{\circ} \mathrm{C}$ nerverenerver

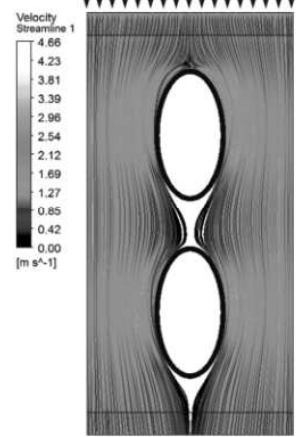

$\mathrm{w}_{\mathrm{e}}=2.5 \mathrm{~m} / \mathrm{s}, \mathrm{T}_{\mathrm{f}}=14.98{ }^{\circ} \mathrm{C}$

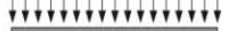
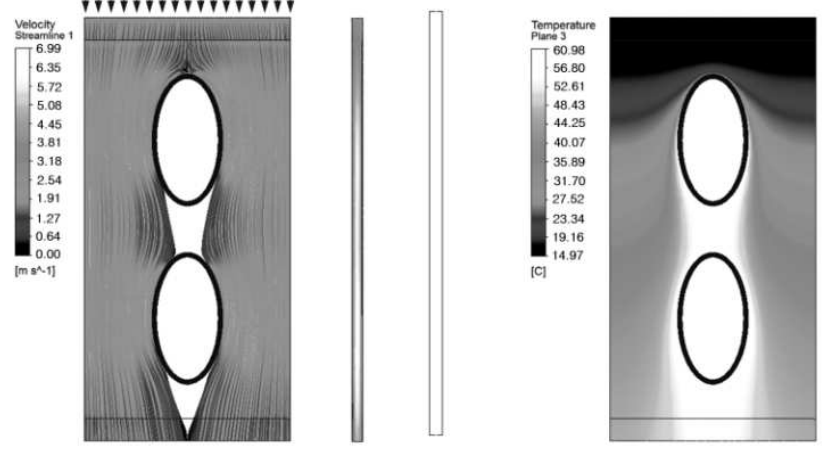

c)
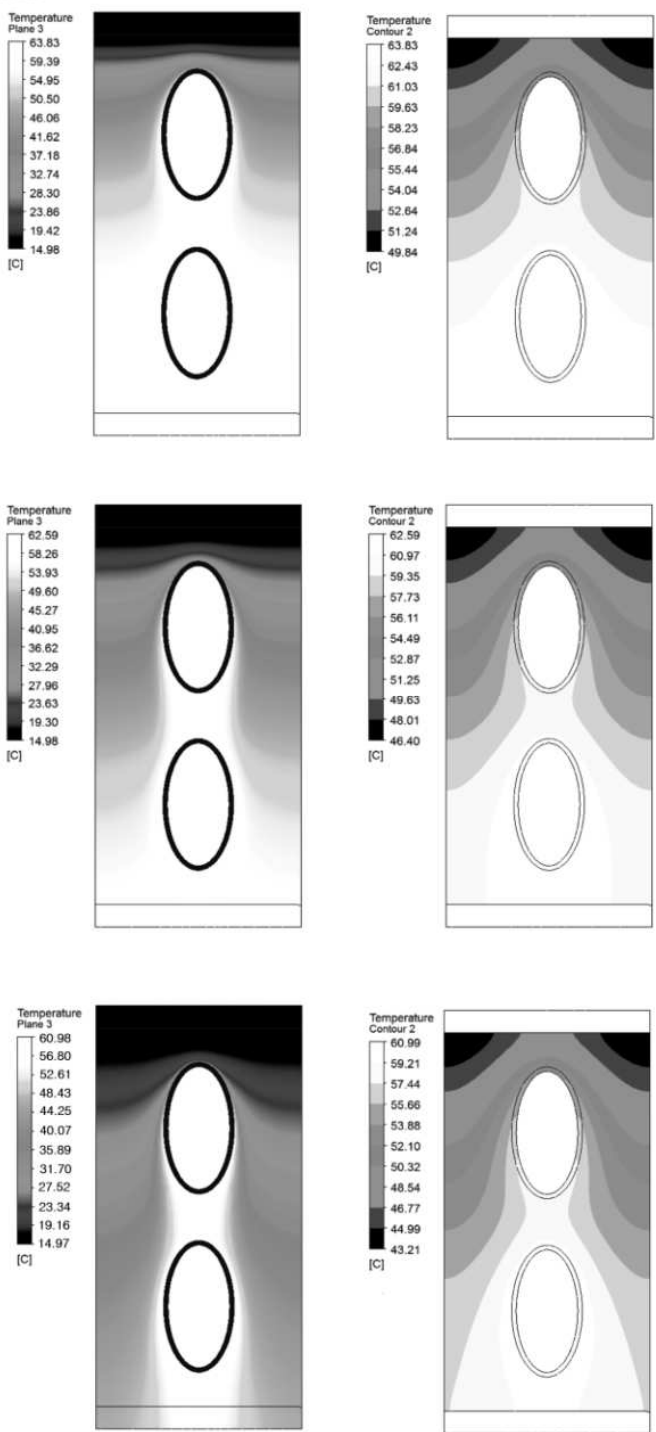

Fig. 4. The results of the test CFD simulation: a) air velocity distribution, b) air temperature evaluated in the middle of flow passage, c) wall temperature (tube and fin) obtained for different values of air inlet velocity $w_{0}$. The bulk temperature of water $\bar{T}_{w}=65^{\circ} \mathrm{C}$. 
The values of the average heat transfer coefficients $h_{a v g}, C F D$ are listed in Table 1. The computations were carried out for the mean water temperatures $\bar{T}_{w}$ $=65{ }^{\circ} \mathrm{C}$ (case no $1-9$ ) and $\bar{T}_{w}=30^{\circ} \mathrm{C}$ (case no 10-18) to demonstrate that the influence of the tube wall temperature on the determined air side heat transfer coefficients is insignificant. The maximum relative difference between the heat transfer coefficients for $\bar{T}_{w}=30{ }^{\circ} \mathrm{C}$ and $\bar{T}_{w}=65^{\circ} \mathrm{C}$ does not exceed $2.9 \%$.

Table 1. The values of the heat transfer rate $Q$ referenced to a single pitch, the area averaged wall temperature $\bar{T}_{\text {wall }}$, the bulk temperature of the air $T_{\infty}$ and the average heat transfer coefficient $h_{\text {avg }, C F D}$ for the air flow, obtained for the performed computational cases.

\begin{tabular}{|c|c|c|c|c|c|}
\hline Case no. & $w_{0}, \mathrm{~m} / \mathrm{s}$ & $Q, \mathrm{~W}$ & $\bar{T}_{\text {wall }},{ }^{\circ} \mathrm{C}$ & $\bar{T}_{a}=T_{\infty},{ }^{\circ} \mathrm{C}$ & $h_{\text {avg }, C F D}, \mathrm{~W} /\left(\mathrm{m}^{2} \mathrm{~K}\right)$ \\
\hline 1 & 1 & 0.8609 & 59.049 & 37.014 & 39.385 \\
\hline 2 & 1.2 & 1.0089 & 58.059 & 36.521 & 47.121 \\
\hline 3 & 1.4 & 1.1445 & 57.152 & 36.066 & 54.155 \\
\hline 4 & 1.6 & 1.2678 & 56.321 & 35.651 & 60.347 \\
\hline 5 & 1.8 & 1.3804 & 55.569 & 35.275 & 65.849 \\
\hline 6 & 2 & 1.4806 & 54.865 & 34.922 & 70.589 \\
\hline 7 & 2.2 & 1.575 & 54.247 & 34.614 & 74.774 \\
\hline 8 & 2.4 & 1.6608 & 53.672 & 34.326 & 78.506 \\
\hline 9 & 2.5 & 1.7007 & 53.403 & 34.191 & 80.204 \\
\hline 10 & 1 & 0.2570 & 28.228 & 21.604 & 38.913 \\
\hline 11 & 1.2 & 0.3010 & 27.938 & 21.459 & 46.399 \\
\hline 12 & 1.4 & 0.3405 & 27.661 & 21.321 & 53.069 \\
\hline 13 & 1.6 & 0.3765 & 27.416 & 21.198 & 58.935 \\
\hline 14 & 1.8 & 0.4091 & 27.186 & 21.083 & 64.106 \\
\hline 15 & 2 & 0.4392 & 26.989 & 20.985 & 68.628 \\
\hline 16 & 2.2 & 0.4662 & 26.798 & 20.889 & 72.563 \\
\hline 17 & 2.4 & 0.4913 & 26.625 & 20.803 & 76.083 \\
\hline 18 & 2.5 & 0.5039 & 26.551 & 20.765 & 77.804 \\
\hline
\end{tabular}

The values of $h_{a, C F D}$ obtained when $\bar{T}_{w}=30{ }^{\circ} \mathrm{C}$ (case no 1-9) and $\bar{T}_{w}=65$ ${ }^{\circ} \mathrm{C}$ (case no 10-18) do not differ significantly for the same velocity of the air flow. In order to assess if the presented method for the determination of the average heat transfer coefficient is correct, the performance tests of the heat exchanger, presented in Fig. 2 are carried out. Based on them the correlations for the air side Nusselt number $\mathrm{Nu}_{\mathrm{a}}$ are obtained.

\section{Comparison of the Nusselt number correlations determined experimentally and via the CFD simulations}

The experimental-numerical method for determining the average heat transfer coefficient for the air flow $h_{a}$ was described in details in refferences [7, 10]. Moreover, in reference [10], the detailed list of measurement points, used in this work, is given. The experimental-numerical method is based on the performance tests of a car radiator (see Fig. 1 and Fig. 2) and allows to obtain 
the correlations for the Nusselt number for the air and water flows, based on the mathermatical model of fin-and-tube heat exchanger developed in [5]. The following parameters of the cross-flow heat exchanger are measured: the inlet and outlet air temperatures $-T_{a,}{ }_{a}, T,{ }_{a}$; the inlet and outlet water temperatures $T{ }^{\prime}, T,{ }^{\prime}{ }_{w}$, the volumetric mass flow rate of water $\dot{V}_{w}$ and the inlet velocity of the air $w_{0}$. During the measurements the following ranges of $T_{a}{ }_{a}, T^{\prime}{ }^{\prime}{ }_{a}, \dot{V}_{w}, T^{\prime}{ }_{w}$, $T^{\prime \prime}{ }^{\prime \prime}$ and $w_{0}$ are examined: $T^{\prime}{ }_{a}=12.5^{\circ} \mathrm{C}-15{ }^{\circ} \mathrm{C}, T^{\prime,}{ }_{a}=38.51{ }^{\circ} \mathrm{C}-57.66^{\circ} \mathrm{C}$, $\dot{V}_{w}=865.8 \mathrm{dm}^{3} / \mathrm{h}-2186.40 \mathrm{dm}^{3} / \mathrm{h}, T^{,}{ }_{w}=61.0^{\circ} \mathrm{C}-71.08^{\circ} \mathrm{C}, T^{,},{ }_{w}=49.58^{\circ} \mathrm{C}-$ $63.83{ }^{\circ} \mathrm{C}, w_{0}=1 \mathrm{~m} / \mathrm{s}-2.2 \mathrm{~m} / \mathrm{s}$.

The Nusselt number correlations for the air flow, determined upon the experimental-numerical method, are listed in Table 2. These correlations are paired with the heat transfer formulas for water flow, presented in literature [1921], which were used in the mathematical model of the fin-and-tube heat exchanger [11] to determine the outlet temperature of water $T_{w}^{\prime \prime \prime}$.

Table 2. Nusselt number formulas for the air flow $\mathrm{Nu}_{\mathrm{a}}$ obtained from the measurements.

\begin{tabular}{|c|c|c|c|}
\hline No. & Correlation - experiment & & $\begin{array}{c}\text { Estimated } \\
\text { parameters }\end{array}$ \\
\hline 1 & $\begin{array}{l}\mathrm{Nu}_{\mathrm{a}}=x_{1} \operatorname{Re}_{\mathrm{a}}^{x_{2}} \operatorname{Pr}_{\mathrm{a}}^{1 / 3} \text { (experiment) } \\
\mathrm{Nu}_{\mathrm{w}}=\frac{(\xi / 8)\left(\operatorname{Re}_{\mathrm{w}}-1000\right) \operatorname{Pr}_{\mathrm{w}}}{1+12.7 \sqrt{(\xi / 8)}\left(\operatorname{Pr}_{\mathrm{w}}^{2 / 3}-1\right)}\left[1+\left(\frac{d_{t}}{L_{t}}\right)^{2 / 3}\right]\end{array}$ & [19] & $\begin{array}{c}S_{\min }=0.6678 \mathrm{~K}^{2} \\
s_{t}=0.1102 \mathrm{~K} \\
x_{1}=0.1117 \pm 0.0024 \\
x_{2}=0.6469 \pm 0.0045\end{array}$ \\
\hline 2 & $\begin{array}{l}\mathrm{Nu}_{\mathrm{a}}=x_{1} \operatorname{Re}_{\mathrm{a}}^{x_{2}} \operatorname{Pr}_{\mathrm{a}}^{1 / 3} \text { (experiment) } \\
\mathrm{Nu}_{\mathrm{w}}=\frac{(\xi / 8)\left(\operatorname{Re}_{\mathrm{w}}-1000\right) \operatorname{Pr}_{\mathrm{w}}}{k_{1}+12.7 \sqrt{(\xi / 8)}\left(\operatorname{Pr}_{\mathrm{w}}^{2 / 3}-1\right)}\left[1+\left(\frac{d_{t}}{L_{t}}\right)^{2 / 3}\right. \\
k_{1}=1.07+\frac{900}{\operatorname{Re}_{\mathrm{w}}}+\frac{0.63}{\left(1+10 \operatorname{Pr}_{\mathrm{w}}\right)}\end{array}$ & & $\begin{array}{c}S_{\min }=1.2799 \mathrm{~K}^{2} \\
s_{t}=0.1540 \mathrm{~K} \\
x_{1}=0.1309 \pm 0.00418 \\
x_{2}=0.6107 \pm 0.0559\end{array}$ \\
\hline 3 & $\begin{array}{l}\mathrm{Nu}_{\mathrm{a}}=x_{1} \operatorname{Re}_{\mathrm{a}}^{x_{2}} \operatorname{Pr}_{\mathrm{a}}^{1 / 3} \text { (experiment) } \\
\mathrm{Nu}_{\mathrm{w}}=\frac{(\xi / 8) \operatorname{Re}_{\mathrm{w}} \operatorname{Pr}_{\mathrm{w}}}{1+8.7 \sqrt{(\xi / 8)}\left(\operatorname{Pr}_{\mathrm{w}}-1\right)}\left[1+\left(\frac{d_{t}}{L_{t}}\right)^{2 / 3}\right]\end{array}$ & [21] & $\begin{array}{c}S_{\min }=1.4034 \mathrm{~K}^{2} \\
s_{t}=0.1569 \mathrm{~K} \\
x_{1}=0.1212 \pm 0.0398 \\
x_{2}=0.6258 \pm 0.0595\end{array}$ \\
\hline
\end{tabular}

The air-side Nusselt number formulas obtained based on the values of the average heat transfer coefficients $h_{\text {avg,CFD }}$ (see Table 1), are given in Table 3. These correlations involves the criteria number definition $\left(\mathrm{Nu}_{\mathrm{a}}, \operatorname{Re}_{\mathrm{a}}, \operatorname{Pr}_{\mathrm{a}}\right.$ and $\mathrm{Nu}_{\mathrm{w}}, \mathrm{Re}_{\mathrm{w}}$, and $\mathrm{Pr}_{\mathrm{w}}$ ) given in [10]. 
Table 3. Nusselt number formulas for the air flow $\mathrm{Nu}_{\mathrm{a}}$ obtained from the CFD simulations based on the mean arithmetic temperatures of the air: $T_{\infty}=65^{\circ} \mathrm{C}$ and $T_{\infty}=30^{\circ} \mathrm{C}$.

\begin{tabular}{|c|c|c|}
\hline No. & Correlation - CFD simulations & $\begin{array}{c}\text { Estimated } \\
\text { parameters }\end{array}$ \\
\hline 1 & $\begin{array}{c}\mathrm{Nu}_{\mathrm{a}}\left(T_{\infty}=65^{\circ} \mathrm{C}\right)=x_{1} \operatorname{Re}_{\mathrm{a}}^{x_{2}} \operatorname{Pr}_{\mathrm{a}}^{1 / 3} \\
150<\operatorname{Re}_{\mathrm{a}}<400, \operatorname{Pr}_{\mathrm{a}}=0.7\end{array}$ & $\begin{array}{c}x_{1}=0.0674 \pm 0.00621 \\
x_{2}=0.7152 \pm 0.0612\end{array}$ \\
\hline 2 & $\begin{array}{c}\mathrm{Nu}_{\mathrm{a}}\left(T_{\infty}=30^{\circ} \mathrm{C}\right)=x_{1} \operatorname{Re}_{\mathrm{a}}^{x_{2}} \operatorname{Pr}_{\mathrm{a}}^{1 / 3} \\
150<\operatorname{Re}_{\mathrm{a}}<400, \operatorname{Pr}_{\mathrm{a}}=0.7\end{array}$ & $\begin{array}{c}x_{1}=0.0623 \pm 0.00574 \\
x_{2}=0.7336 \pm 0.0703\end{array}$ \\
\hline
\end{tabular}

Due to the slight differences in the computed heat transfer coefficients (Table 1), also the heat transfer correlations shown in Table 4 differ slightly from each other (Fig. 5a).The estimated parameters $x_{1}$ and $x_{2}$ were determined using a Curve Fitting toolbox of the MATLAB R2013 software [22] using the least square method.

The Nusselt number correlations obtained for the air flow using the CFD simulations (see Table 4) are compared with the experimental correlations listed in Table 3. In Fig. 5a, one can observe, that the correlations for the Nusselt number for the air flow, based on the CFD simulations, predicts slightly lower values than the one obtained via the measurements. The maximum percentage differences can be observed for $\operatorname{Re}_{\mathrm{a}}=150$, where the values of the Nusselt number, obtained using the CFD simulations are from $10.1 \%$ to $13.7 \%$ lower than the ones obtained from the measurements. For the largest value of $\operatorname{Re}_{\mathrm{a}}\left(\mathrm{Re}_{\mathrm{a}}\right.$ $=400)$ these differences are smaller: from $0.5 \%$ to $8.4 \%$.

(a)

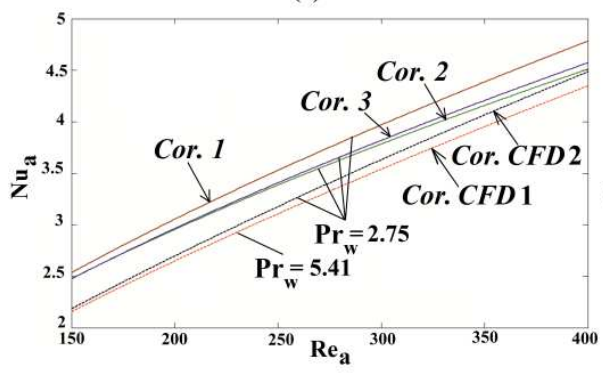

(b)

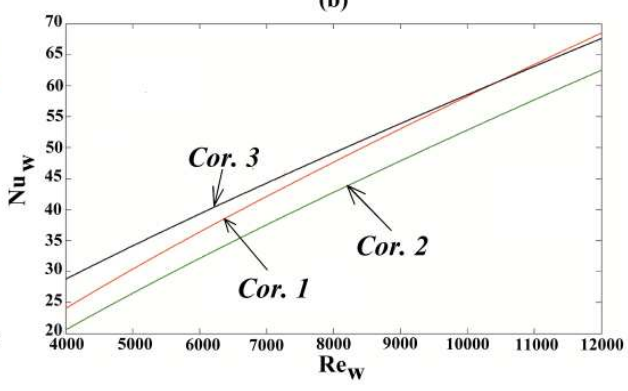

Fig. 5. The values of the Nusselt number of the air $\mathrm{Nu}_{\mathrm{a}}-\mathrm{a}$ ) obtained for the Reynolds numbers $\operatorname{Re}_{\mathrm{a}}=150-400$ and the Prandtl number $\operatorname{Pr}_{\mathrm{a}}=0.7$, using the correlations listed in Table 2 (experimental correlations - Cor. 1 - Cor. 3 ) and in Table 3 (correlations based on CFD simulations Cor. CFD 1, Cor. CFD 2); The values of the Nusselt number of water $\mathrm{Nu}_{\mathrm{w}}$ - b) obtained for the Reynolds numbers $\operatorname{Re}_{\mathrm{w}}=4000-12000$ and the Prandtl number $\operatorname{Pr}_{\mathrm{w}}=2.75$ using the correlations given in Table 2. 
The values of the Prandtl numbers for the air and water: $\operatorname{Pr}_{a}=0.7$ and $\operatorname{Pr}_{w}=$ 2.75 are typical for air temperatures $\bar{T}_{a}$ from $10{ }^{\circ} \mathrm{C}$ to $40{ }^{\circ} \mathrm{C}$ and for water temperature $\bar{T}_{w}=65^{\circ} \mathrm{C}$. Comparing Fig. 5a and Fig. 5b, one can observe that the experimental correlation 1 (see Table 3) predicts the largest values of the Nusselt number for the air flow if $\mathrm{Re}_{\mathrm{a}}>150$ and for water flow if $\mathrm{Re}_{\mathrm{w}}>10364$. Experimental correlation 2 predicts the lowest values of the Nusselt number for the air flow if $\mathrm{Re}_{\mathrm{a}}>150$ and for water flow if $\mathrm{Re}_{\mathrm{w}}>4000$. Experimental correlation 3 predicts slightly larger values of $\mathrm{Nu}_{\mathrm{a}}$ if $\mathrm{Re}_{\mathrm{a}}>150$ and the largest values of $\mathrm{Nu}_{\mathrm{w}}$ if $\mathrm{Re}_{\mathrm{w}}<10364$.

During the CFD simulations the idealistic heat transfer conditions were assumed: the constant inlet velocity and the perfect contact between the fin and the outer surface of tube wall. In a real device the non uniform distribution of air flow at the inflow to the narrow passage formed between the fins as well as the thermal contact resistance between the fin and tube [11] can strongly influence the heat and momentum transfer processes. Furthermore, the non uniform distribution of water flow to the tubes of heat exchanger exists for these devices $[14,15]$.The above mentioned circumstances explain why the Nusselt number correlations obtained using CFD simmulations differ slightly from the experimental.

\section{Conclusions}

The paper presents the determination of the average air-side heat transfer coefficient for a fin-and-tube heat exchanger, based on the CFD simulations. The determined correlations for the Nusselt number are compared with the experimental results. The CFD simulations were carried out using the SST (Shear Stress Transport) turbulence model with the Gamma-Theta transitional turbulence formulation, proposed by Lengthry and Menter. The computations assume that the bulk temperature of air is equal to the mean arithmetic temperature of the inlet and outlet air temperatures.

The studied range of Reynolds number is: $\mathrm{Re}_{\mathrm{a}} \in 150-400$ and the Prandtl number $\operatorname{Pr}_{\mathrm{a}}$ is equal 0.7. Comparing the air-side Nusselt numbers determined based on CFD simulations and by the experiment, the largest obtained differences are up to $13.7 \%$. For the analysed change range of $\mathrm{Re}_{\mathrm{a}}$ the CFD based method predicts lower values of the Nusselt number than these determined experimentally. This situation can be influenced by flow maldistributions of the fluids (air, and water) in tested heat exchanger as well as the existence of thermal contact resistance between the fin and the tube, which strongly reduces the heat transfer rate. 


\section{References}

[1] Matos R. S., Vargas J. V. C., Laursen T. A., Bejan A., 2004: Optimally staggered finned circular and elliptic tubes in forced convection, International Journal of Heat and Mass Transfer 47(6-7): 1347-1359.

[2] Jang J. Y., Yang J. Y., 1998: Experimental and Numerical Analysis of the ThermalHydraulic Characteristics of Elliptic Finned-Tube Heat Exchangers, Heat Transfer Engineering 19(4): 55-67.

[3] Li. B., Feng B., He Y. L., Tao W.Q., 2006: Experimental study on friction factor and numerical simulation on flow and heat transfer in an alternating elliptical axis tube, Applied Thermal Engineering, 26(17-18): 2336-2344.

[4] Nishiyama H., Ota T., Matsumo T., 1988: Heat Transfer and Flow around an Elliptic Cylinders in Tandem Arrangement, JSME International Journal Series II, Vol. 31: 410-419.

[5] Taler D., 2002: Theoretical and experimental analysis of heat exchangers with extended surfaces, Polish Academy of Science publishing press, ISBN 83-915470-19, Poland.

[6] Taler D., 2004: Determination of heat transfer correlations for plate-fin-and-tube heat exchangers, Heat and Mass Transfer, Vol. 40: 809-822.

[7] Taler D., 2007a: Experimental and numerical predictions of the heat transfer correlations in the cross-flow plate fin and tube heat exchangers, Archives of Thermodynamics 28(2): 3-18.

[8] Taler D., 2007b: Effect of thermal contact resistance on the heat transfer in plate finned tube heat exchangers, ECI Symposium Series, Volume RP5: Proceedings of 7th International Conference on Heat Exchanger Fouling and Cleaning - Challenges and Opportunities, pp. 362-371, H Müller-Steinhagen, M. R. Malayeri, P. Watkinson (Eds.), Engineering Conferences International, Tomar, Portugal.

[9] Taler D., 2009: Dynamics of Tube Heat Exchangers (in Polish), Monograph 193, AGH University of Science and Technology Press, ISSN 0867-6631, Cracow, Poland.

[10] Taler D., 2013: Experimental determination of correlations for average heat transfer coefficients in heat exchangers on both fluid sides, Heat and Mass Transfer, Vol. 49. 1125-1139.

[11] Taler, D., Cebula, A., 2010: A new method for determination of thermal contact resistance of a fin-to-tube attachment in plate fin-and-tube heat exchangers, Chemical and Process Engineering 31(4): 839-855.

[12] Taler J., Taler D., Sobota T., Cebula A., 2012: Theoretical and Experimental Study of Flow and Heat Transfer in a Tube Bank, in V. M. Pertowa (Ed), Advances in Engineering Research, Vol. 1, Nova Science Publishers Inc., pp. 1-56 ,New York.

[13] Łopata, S., Ocłon, P., 2010: Investigation of the flow conditions in a highperformance heat exchanger, Archives of Thermodynamics 31(3): 37-50.

[14] Łopata, S., Ocłoń, P., 2012a: Analysis of operating conditions for high performance heat exchanger with the finned elliptical tube, Rynek Energii 102(5): 112-124. 
[15] Łopata S., Ocłoń, P., 2012b: Modelling and Optimizing Operating Conditions of Heat Exchanger with Finned Elliptical Tubes, in Fluid Dynamics, Computational Modeling and Applications, L. Hector Juarez (Ed.), ISBN: 978-953-51-0052-2, pp. 327- 356, InTech.

[16] ANSYS CFX, 2009: Solver Theory Guide r12, ANSYS Inc.

[17] Chung T. J., 2010: Computational Fluid Dynamics 2nd ed., ISBN 9780521769693, Cambridge University Press, USA.

[18] Langtry R. B., Menter F. R., 2005: Transition Modeling for General CFD Applications in Aeronautics, AIAA paper.

[19] Gnielinski, V., 1976: Neue Gleichungen für den Wärme- und den Stoffübergang in turbulent durchströmten Rohren und Kanälen, Forschung im Ingenieurwesen 41(1): 8-16.

[20] Pietukhov B. S., Popov V. N., 1963: Theoretical Calculations of Heat Transfer in Turbulent Flow in Tubes of an Incompressible Fluid with Variable Physical Properties, High Temperature Institute Paper, 1(1), pp. 69-83.

[21] Bejan A., 2003: Forced Convection: Internal Flows, Chapter 5 in Heat Transfer Handbook, Bejan A. Kraus S. (Eds.), ISBN 978-0-471-39015-2, Wiley, Hoboken.

[22] MATLAB, 2013, MATLAB online doccumentation:

http://www.mathworks.com/help/matlab, MathWorks

\section{NUMERYCZNE WYZNACZANIE ŚREDNICH WSPÓŁCZYNNIKÓW WYMIANY CIEPLA W WYMIENNIKU ŻEBROWO-RUROWYM}

\section{Streszczenie}

Artykuł prezentuje metodę numeryczną określania średniego współczynnika wymiany ciepła. Formuły do obliczania liczby Nusselta określono za pomoca metody opartej na symulacji CFD. Trajektoria wypływu gazu w poprzek wewnętrznej przestrzeni rurowej wymiennika ciepła jest złożona, dlatego wykorzystano symulacje CFD do określenia rozkładów prędkości i pola temperatury powietrza. Wyniki obliczeń numerycznych porównano z formułą określającą liczbę Nusselta na podstawie danych eksperymentalnych, które otrzymano podczas badań chłodnicy samochodowej. Osiągnięto wysoka zgodność pomiędzy wynikami numerycznymi oraz eksperymentalnymi.

Słowa kluczowe: współczynnik przejmowania ciepła, żebrowo-rurowy wymiennik ciepła, symulacje CFD, rury owalne

DOI: 10.7862/rm.2014.29

Otrzymano/received: 15.05 .2014

Zaakceptowano/accepted: 20.06 .2014 